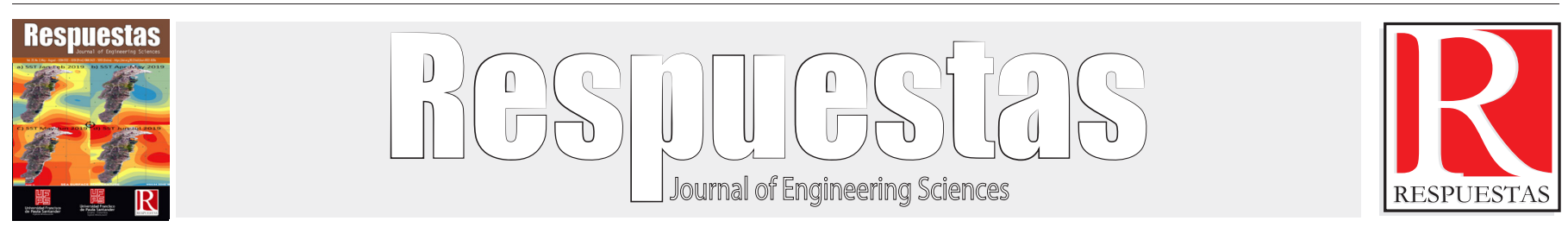

Original Article

https://doi.org/10.22463/0122820X.2959

\title{
Review of the use of nanomaterials in soils for construction of roads
}

Estado del arte del uso de nano materiales en suelos para construcción de carreteras

Jhon Fredy Rincón-Morantes ${ }^{1}$, Oscar Javier Reyes-Ortiz², Juan Carlos Ruge-Cardenas ${ }^{3}$

'Magister en Infraestructura Vial, jhon.rincon@esmic.edu.co, Escuela Militar de Cadetes “General José María Córdova”, Capitán Ejército Nacional, Director de programa de Ingenieria Civil, orcid.org/00000002-4626-4365, Avenida calle 80 \#38-00, 3202743218, Bogotá D.C., Colombia.

²Doctor en Gestión del Territorio e Infraestructura, oscarreyes@unimilitar.edu.co, Universidad Militar Nueva Granada, Profesor Titular, Programa de Ingeniería Civil, Lider Grupo de Investigación Geotecnia, orcid.org/0000-0002-2001-2450, Carrera 11 \#101-80, Bogotá D.C., Colombia.

${ }^{3}$ Doctor en Geotecnia, juan.ruge@unimilitar.edu.co, Universidad Militar Nueva Granada, Profesor Asistente, Programa de Ingeniería Civil, Grupo de Investigación Geotecnia, orcid.org/0000-0002-9100-6058, Carrera 11 \#101-80, Bogotá D.C., Colombia.

How to cite: J.F. Rincón-Morantes, O.J. Reyes-Ortiz, J.C. Ruge-Cardenas, "Review of the use of nanomaterials in soils for construction of roads". Respuestas, vol. 25, no. 2, pp. 213-223, 2020

Received on June 30, 2019; Approved on November 10, 2019

\begin{tabular}{ll}
\hline Keywords: & ABSTRACT \\
\hline $\begin{array}{l}\text { Nano materials are becoming more and more relevant in the construction of civil works, since they } \\
\text { nano material, } \\
\text { nano fibers, } \\
\text { fine soils at the level of subgrade, sub-bases, bases and even for filters in water treatment. This article } \\
\text { nano fibers, } \\
\text { soils, } \\
\text { the mechanical and geotechnical properties of soils used in road construction, especially what has to } \\
\text { do with the manufacture of nano fibers for use in soils; finding that its use in the field of roads is to be } \\
\text { investigated and developed with different types of solutions, as the most studied are the carbon nano fibers. }\end{array}$ \\
\hline $\begin{array}{l}\text { Palabras clave: } \\
\text { nanotecnología, }\end{array}$ \\
$\begin{array}{l}\text { Los nano materiales toman cada vez más relevancia en la construcción de obras civiles, ya que se pueden } \\
\text { usar como adiciones o aditivos para mejorar y estabilizar concretos asfalticos, concretos hidráulicos, suelos } \\
\text { fibras, } \\
\text { finos a nivel de sub rasantes, sub bases, bases e inclusive para filtros en el tratamiento de aguas. El presente } \\
\text { artículo pretende recolectar las distintas experiencias plasmadas por la ciencia en el uso de nano materiales, } \\
\text { con el fin de estabilizar o mejorar las propiedades mecánicas y geotécnicas de los suelos usados en la } \\
\text { suelos, } \\
\text { arcillas. }\end{array}$
\end{tabular}

\section{Introduction}

All civil works are founded on soil, whether natural, stabilized or improved; normally the natural soil does not have the adequate characteristics to serve as the foundation of an infrastructure, which requires that the soils be competent so that the works are not vulnerable to the different seismic and load variables, for this reason stabilization or improvement procedures are carried out in order to reinforce geotechnical properties to comply with certain standards of durability, permeability, volume stability, resistance and compressibility or deformation. Mainly fine soils such as clays, silts or mineral fillers are stabilized or improved, taking into account that the surface area of the particles is greater with respect to that of granular materials, since these are elongated and flattened [1] - [3].

Taking into account that roads are mainly built with selected granular materials, arranged in different layers that make up the subbase, base and asphalt mixes, each of them containing fine materials defined as mineral fillers that have plasticity indexes that must be controlled; In addition, the subgrade may contain clayey materials that can be expansive; therefore, in order to meet the standards, these soils are stabilized and improved with common materials such as cement, lime, fly ash, silica fume, fibers, among other materials [4], [5]. 
Studies have been made to use non-common materials for roads and other civil works, such as natural fibers from date palm, coconut, bamboo, jute, hemp, among other plants [6], [7]; for the improvement of subgrade soils, sub-bases and bases for roads, finding an increase in the C. B.R. by improving the tensile strength between particles, increasing the angle of internal friction and even increasing permeability; however, its low production cost is affected by the low durability of the fibers [8] - [10].

Historically, one of the problematic soils has been expansive clays, because they have very high volume variations in very short times, due to external factors such as moisture and desiccation. Several studies have been carried out to control this phenomenon, such as the use of sulfonated oil [11]; however, in the search for new materials to control and improve these and other properties of soils, experiments are being carried out with different nano materials, which in clays can manipulate their structure and their interaction with water, resulting in a better behavior within the layers of a pavement [12].

\section{Nanotechnology in the construction sector}

Nanotechnology is a field that has developed over the last five decades, it works with the structural units of materials to change their unique characteristics, the philosophy on which it works is with the addition of nano materials to a common material, in order to greatly improve the properties of such material, In the construction sector, the aim is to have composite materials that are lighter, more resistant, have better adherence, reduce thermal and acoustic susceptibility, and even create materials that function as sensors in hydraulic concretes to detect changes in temperature, humidity and micro cracks at early ages [13]-[15].

Nano materials are distinguished by having a size smaller than $100 \mathrm{~nm}$ in diameter, developed by methods of synthesis of materials in gaseous, liquid or solid state, which are generally sought to have a morphology, chemical composition, microstructures and purity desired for the application of different technologies in the field of chemistry, biomedical, electronics and others [16], [17]. Table I shows the different types of structures that can be achieved in the field of nano materials and their fabrication methods that are currently under development, which initially have a high cost due to the fabrication equipment, but are compensated throughout the life span of the works [18].

Table I. Types of nanostructures and their fabrication methods

\begin{tabular}{|c|c|}
\hline Nano structures & Manufacturing methods \\
\hline Aerogels & \\
Carbon nanotubes & Electron beam lithography \\
Dendrimers & Nanoimprint lithography \\
Magnetic molecules & Chemical vapor deposition \\
Nano metallic particles & Focused ion beams \\
Nano clays & Pulsed laser deposition \\
Photonic crystals & Sputtering deposition \\
Quantum corrals & Molecular self-assembly \\
Self-assembled monolayers & Hydrothermal synthesis \\
Nanowires & Molecular beam epitaxy \\
Semiconductor quantum dots & Electrospinning \\
Fluorescent semiconductor nanocrystals & \\
\hline
\end{tabular}

With the understanding that nanotechnology can change nano properties and these in turn change macro properties, nano materials have been developed in construction such as: Carbon Nanotubes (CNT), Carbon Nanofibers (CNF), Nano silica (N-silica), Polyhedral Oligomeric Silsesquioxane (POSS), Montmorillonite organoclay (MMT), Titanium dioxide nanoparticles (TiO2), Silver nanoparticles (Ag), aluminum oxide nanoparticles (A12O3), silicon dioxide nanoparticles ( $\mathrm{SiO} 2)$, zirconium oxide nanoparticles $(\mathrm{ZrO} 2)$, zinc oxide nanoparticles $(\mathrm{ZnO})$, Wolfram (Tungsten) Oxide nanoparticles (WO3); the inclusion of a small percentage of these nanoparticles can produce extraordinary 
changes in the properties of the materials used for construction and even on natural soil [19] - [21].

Currently, the use of nanomaterials in road construction has already been reported as shown in Table II, where it can be observed that in India they have been used in different fields and that they help in road safety issues, however, there is still a limitation in their use due to their production cost [22]. Even in the United States there is a budget of billions of dollars for the development of nano materials that contribute, among others, to the improvement of the resistance of construction materials [23].

Table II. Overview of nanoparticles and their application

\begin{tabular}{|c|c|c|}
\hline No. & Nano particles & Areas of application \\
\hline 1 & Nano-silica $\left(\mathrm{SiO}_{2}\right)$ & $\begin{array}{l}\text { - Replaces part of the cement to densify concrete and obtain early strength } \\
\quad \text { Improves pavement surface characteristics }\end{array}$ \\
\hline 2 & Micro silica (silica fume) & Increases compressive strength and flexural strength in concrete \\
\hline 3 & $\begin{array}{l}\text { Nano carbon tubes (SWCNTs or } \\
\text { MWCNTs) }\end{array}$ & $\begin{array}{l}\text { - Increases compressive strength and flexural strength in concrete } \\
\text { - } \quad \text { Can be used in concrete as a sensor to monitor structural conditions }\end{array}$ \\
\hline 4 & Nano phosphorus & $\bullet \quad$ Improving road visibility \\
\hline 5 & Nano $\mathrm{TiO}_{2}$ & Self-cleaning of concrete pavement \\
\hline 6 & Polymeric fiber matrix with nano silica & Self-structural Health Monitoring System in Repairs and Rehabilitations \\
\hline 7 & $\begin{array}{l}\text { High performance steel using copper } \\
\text { nanoparticles }\end{array}$ & In bridges for corrosion resistance and improved weldability \\
\hline 8 & Nanotechnology enabled sensors & $\begin{array}{l}\text { For monitoring and controlling temperature, humidity, smoke, noise, stresses, } \\
\text { vibrations, cracks and corrosion }\end{array}$ \\
\hline
\end{tabular}

It is even being studied as waste materials that are used on a macro scale such as fly ash, these being synthesized at nano levels, can be used as an additive to stabilize noncompetent soils, in the expectation that with the increase of the surface area of the soil, the mechanical properties of the soil will be improved in general [24].

\section{Use of nanotechnology to stabilize soils}

The importance of soil stabilization from the point of view of nanotechnology is because soil has a great variety of sizes ranging from nanometers to millimeters $(1 \mathrm{~nm}-75 \mathrm{~mm})$ [25], precisely one of the applications of nanotechnology for soil stabilization is to waterproof soils, It has even been demonstrated that the use of nanochemical substances can improve the bearing capacity of the soil, and although they show a high cost during their construction, in their maintenance phase they can be lower [26] - [28].

The stabilization of subgrades, subbases and bases for road construction is normally done with materials that change the chemical properties of the soil; however, studies have been carried out on fine soils composed of clays and sands that with the addition of polypropylene fibers have improved properties of density, strength, fatigue, deformation and durability, tested in full-scale tests under the action of different traffic loads and also in triaxial tests [29] - [32].

There are records that the use of nanotechnology can help to make soil stabilization a little more economical, since, for example, $2 \%$ of nanosilica replaced $6 \%$ of cement addition in a stabilized base and sub-base; however, more studies are needed, since it was also shown that the bearing capacity of the soil could be increased up to $2 \%$ of nanosilica content and then tended to decrease as the nano-content increased [33]; Other studies have shown that nanosilica alone does not give good results; for example, mixing $1 \%$ with $5 \%$ lime can increase the C. B.R. of the soil under study, this result increased with the addition of more nanosilica up to $3 \%$, where the best results were seen for the subbase, base and subgrade of roads [34], [35]; and even the addition of nanosilica with recycled polyester fibers has shown results that reach $190 \%$ increase in shear strength in clays, with increases in cohesion and the angle of internal friction and reduction of cracks in the compacted soil [36].

At the University of Sains Malaysia (USM) they carried out some tests on stabilizing natural soil, this report shows that nano materials such as nano $\mathrm{Cu}$, nano $\mathrm{Al} 2 \mathrm{O} 3$, nano clays and nano $\mathrm{MgO}$ were mixed in concentrations of $0.0 \%, 0.1 \%, 0.2 \%$ and $0.3 \%$; as a result it was obtained that in its great majority an improvement of the geotechnical properties such as the reduction of 
the plasticity index and the increase of the unconfined compressive strength, and even these additives can reduce the soil shrinkage in desiccation. [37], [38]. However, in other tests with nanoclays, nano copper and nano alumina, it was determined that the nanoclay did not produce a significant improvement with respect to the other two materials tested, and even that if its use is exceeded, it can have negative effects, as was proven when combined with glass fibers; On the other hand, nano copper controls soil expansion and contraction better than nano alumina. Finally, a recommendation is made regarding the use of nano materials because they are susceptible to particle agglomeration, which can have adverse effects on the mechanical properties of the soil [39] - [41]. However, there are studies in which the use of nanoclays has worked to improve the geotechnical properties of soft soils with a slight presence of sand, since the addition of $2 \%$ to $4 \%$ of these nanoparticles increased the compressive strength by up to $22 \%$, the angle of internal friction by up to $17 \%$ and a decrease in the plasticity index of up to $25 \%$ [42]; and it is even seen as a nano material with potential for use in civil engineering with the addition of polymers for the use of a lower percentage of filler in mixtures, showing benefits over fiber composites [43].

On the other hand, work is being developed using a method of synthesis of nanometric ashes from usual waste materials such as quarry dust, tires, recycled paper, fly ash, and other non-conventional ones such as cigarette ash, bagasse, shells of different products such as coconut, almond, and even dried animal bones, among others. These products are burned and pulverized to obtain nano sizes, the resulting ash is collected and can have sizes ranging from $10 \mathrm{~nm}$ to $800 \mathrm{~nm}$. With the above, it is thought that by increasing the surface area of the ash, it can function as an additive and mineral filler, which improve the mechanical properties of the soil [24]. Another experience recorded in Nigeria, where waste materials from agricultural activities such as Palm Bunch Ash (PBA) were used at the nano level to improve the strength of bases and sub-bases with optimum results [44].

In countries such as Nigeria and India, sub-base and subsurface soils were improved with organosilane composite nanomaterials, this nanomaterial was diluted in water in search of a hydrolysis reaction, which when mixed with the soil particles formed a hydrophobic thin film, which is an alkyl siloxane hydroxide type bond, which, like other technologies described above, produce an impermeable and waterproof layer on the soil, which as a result increased the densities with a lower optimum humidity in relation to the unimproved material, and additionally improved the CBR value by more than 2.5 times in the diluted solutions in concentrations of 1:100 and 1:225 with respect to the diluted solutions: 100 and 1:225, with respect to the plasticity index it was possible to transform soils from medium compressibility silts and clays to low compressibility silts and clays, it was possible to decrease the permeability of the soil by approximately $99 \%$ [45][47]; even this nanotechnology of the silane organ with a small amount of $0.07 \%$ and $3 \%$ of cement has been used for the improvement of subgrade, with a result of 3.6 times increase in the original CBR [48].

They also used nano polymers such as CBR PLUS to stabilize granular bases, with results similar to those mentioned above, with increases of up to 6 times with the addition of 1\% CBR PLUS and 9\% silica sand; in terms of costs, it was concluded that a high initial investment is required, but low during its lifetime due to maintenance effects, according to the economic evaluation carried out [49], [50].

Other studies have shown that the use of common materials in soil stabilization, such as lime at the nano level, presents remarkable results in the reduction of porosity and in the unconfined compressive strength of the soil, since with a $0.5 \%$ content of nano lime, the resistance to different humidities increased by more than $300 \%$; these results are approximately 50\% higher than the stabilization made with $5 \%$ lime on natural soil [51].

\section{Nanofiber processing}

Nanofibers have been developed for approximately 60 years, although at present their production at an industrialized level still needs to be improved [52], because their production requires complex methods, the most common and simple is electrospinning, which works by applying a voltage between two electrodes that produces electrostatic forces on a polymeric liquid solution [52], the result is fibers on a collector plate, which can be designed with porosity, structure, arrangement or alignment of the nanofibers; Fibers with a surface area of 
approximately $40 \mathrm{~m} 2 / \mathrm{g}$ and a diameter of less than $100 \mathrm{~nm}$ can be generated [53]-[55].

At the nano level, fibers are still a field to be studied in civil engineering, one of the most reported fibers by authors are carbon fibers, which have replaced carbon nanotubes, since they are cheaper to manufacture and have a good interfacial performance that facilitates the interaction with different matrices [56]; Nowadays there are reports of the use of carbon nanofibers in high performance hydraulic concretes, which improved the strength and workability in the fresh state, as well as increased its density [57], however, there have been problems with the uniform distribution of the fibers within the cement paste, which can generate failures within the concrete [58]. In asphalt concretes, carbon nanofibers improved their mechanical properties such as compressive strength and reduction of micro-cracks within the mixture [59].

Similarly, nanofibers from waste materials have been used for the management of fly ash sludge transported hydraulically in thermoelectric plants [60], and nanofibers have even been made from expanded polystyrene (EPS) waste, as an economical and environmentally responsible method for the management of manufacturing waste [61], which opens the door for these products to have a great potential use in construction as an alternative method for waste management and social and environmental commitment.

\section{Registered uses of nanofibers in soils}

Soil stabilization can be done in three ways: physical, mechanical or chemical (see Figure 1), which seek to improve properties such as compressibility, hydraulic conductivity, density and strength; Some of the chemical methods used are heat as a catalyst for curing (lime), the use of lime/cement to manage plasticity and improve soil strength, resin/ polymers as a binder to improve the soil matrix and reduce dust, nano chemical solutions that mixed with water increase soil bearing capacity and reduce plasticity indices [62], [63]; on the other hand, on the mechanical side, in clayey soils, plastics, polymers and fibers (wood, glass, polypropylene) have been used as mechanical reinforcement, which considerably increase the cohesion and the angle of internal friction of the soil; one of the main difficulties in the use of fibers in clays is based on on-site mixing, but with time it has excellent results, At the nano level it was found that electromagnetic forces dominate over gravity forces, so the use of nanofibers in the soil resulted in an improvement in shear strength and thixotropy, in addition they control the liquid limits, plastic limit and lower bulk density due to the appearance of nano pores [64] - [66].

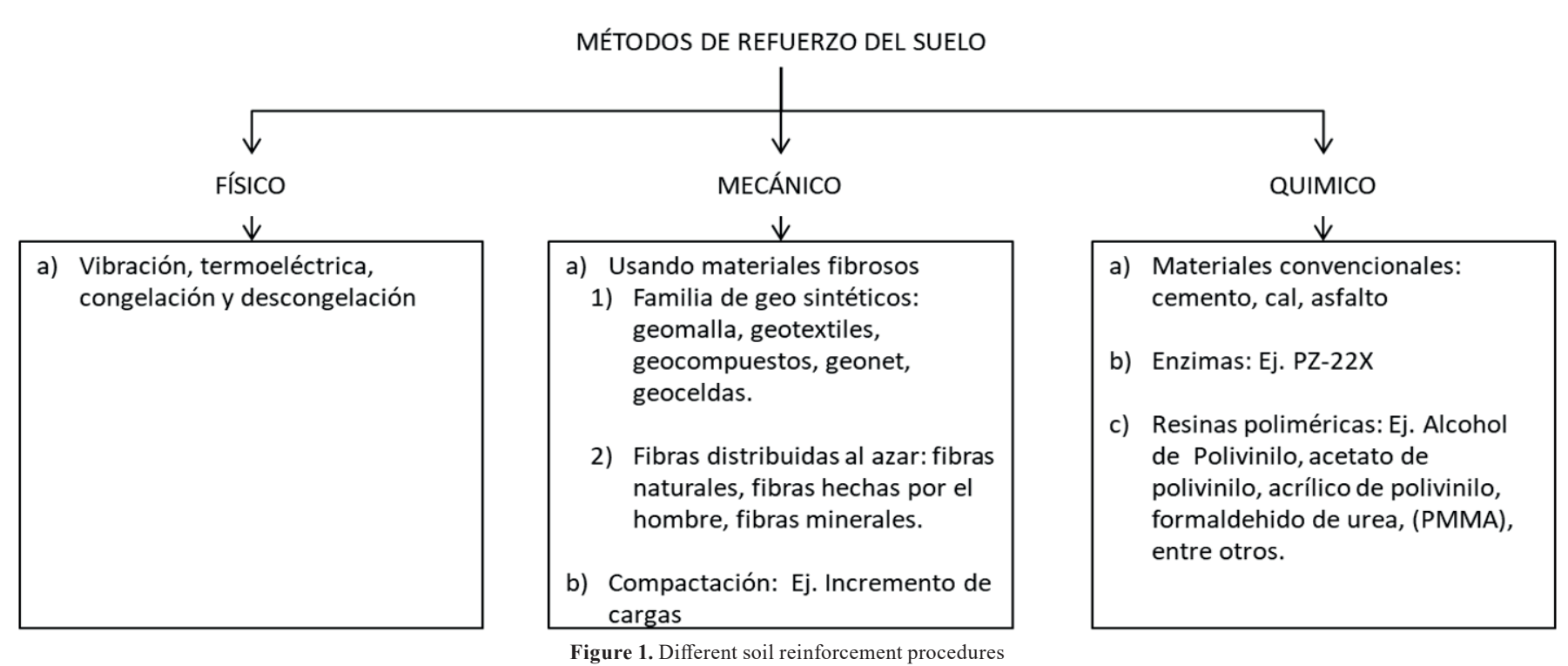

Source: A simple review of soil reinforcement by using natural and synthetic fibers(p. 105) for [63]. 
At the University of Kebangsaan Malaysia (UKM) they were able to demonstrate that with the mixture of less than $0.2 \%$ of carbon nanofibers (purity greater than $98 \%$, diameters $200 \mathrm{~nm}$ and length between 50 and $200 \mathrm{~m}$ ) in residual soils of sandy-clay composition, it is possible to increase the maximum dry density, The density of the nanofibers is higher than that of the natural soil, however, a decrease in porosity and an increase in the hydraulic conductivity of the soil was also observed [67], [68]. They have even worked on the management of expansion and contraction in residual soils with carbon nanofibers, where they found that volumetric shrinkage stress can be reduced by more than $50 \%$, which qualitatively demonstrated that cracks were reduced [69]. Another virtue of carbon nanofibers is that they are a material that chemically are not reactive with other liquid compounds coming from leachates or soil moistures [70].

Taking into account the results described above, the University of Kebangsaan Malaysia investigated the effect of mixing bentonite and carbon nanofibers in three different soil samples, concluding that the shear strength of the soil was indeed improved by increasing the cohesion and friction angle of the tested samples, up to an optimum addition of $0.1 \%$ carbon nanofibers, the mechanism of nano reinforcement is due to the interface bonding and frictional force between the mixed particles [71].

\section{Conclusions}

Although it is registered and evidenced that the use of nano materials improves in general the mechanical and geotechnical properties of soils, its benefits will be presented below:

1. It can be used to improve or stabilize chemically or physically the soil.

2. Nano solutions can waterproof the soil by creating a very thin layer that coats the particles and prevents the passage of water.

3. The nanofibers create bonds between the particles, which reduces and even prevents micro-cracks from appearing on the compacted soil.

4. In general, the use of nano materials in soils improves bearing capacity, shear strength, increases density, reduces plasticity indexes, increases cohesion and friction angle, among other properties.

Its limitation in construction lies in its difficult reproduction at industrial level and in its use on site, which generates higher construction costs; however, it is projected as a method to work on waste management, social and environmental commitment, by incorporating it as a method of recycling non-conventional waste from different industries.

\section{Acknowledgments}

The authors acknowledge and appreciate the financial support of the Colombian National Army, Escuela Militar de Cadetes General José María Córdova, through the project Virtual simulation of laboratory tests of shear strength and deformability in soils; the facilities provided by the Geotechnical Research Group of the Universidad Militar Nueva Granada.

\section{References}

[1] G. P. Makusa, "State of the Art Review Soil Stabilization Methods and Materials," J. State Art Rev., pp. 1-30, 2012.

[2] F. G. Bell, Engineering Treatment of Soils, 1 st. London: E \& FN Spon Taylor \& Francis Group, 1993.

[3] K. C. Onyelowe, "Soil stabilization techniques and procedures in the developing countriesNigeria," Glob. Jour. Engg. Tech., vol. 5, pp. 65-69, 2012.

[4] A. S. Rajpura, "Review of Industrial Waste Used In Stabilization of Expansive Soil in Road Subgrade," Int. J. Adv. Res. Ideas Innov. Technol., vol. 3, no. 2, pp. 1124-1127, 2017.

[5] Y. C. Fung and S. R. Kaniraj, "Comparison of the behavior of fiber and mesh reinforced soils," $J$. Civ. Eng. Sci. Technol., vol. 8, no. 2, pp. 82-88, 2017. 
[6] S. Gowthaman, K. Nakashima, and S. Kawasaki, "A state-of-the-art review on soil reinforcement technology using natural plant fiber materials: Past findings, present trends and future directions," Materials (Basel)., vol. 11, no. 4, 2018.

[7] A. Tiwari and H. K. Mahiyar, "Experimental Study on Stablization of Black Cotton Soil by Fly," Int. J. Emerg. Technol. Advandced Eng., vol. 4, no. 11, pp. 330-333, 2014.

[8] H. Sarbaz, H. Ghiassian, and A. A. Heshmati, "CBR strength of reinforced soil with natural fibres and considering environmental conditions," Int. J. Pavement Eng., vol. 15, no. 7, pp. 577583, 2014.

[9] R. R. Singh and E. S. Mittal, "Improvement of Local Subgrade Soil for Road Constuction By the Use of Coconut Coir Fiber," Int. J. Res. Eng. Technol., vol. 3, no. 5, pp. 707-711, 2014.

[10] M. Ali, "Coconut fibre: A versatile material and its applications in engineering," J. Civ. Eng. Constr. Technol., vol. 2, no. 9, pp. 189-197, 2011.

[11] J. Camacho Tauta, O. J. Reyes Ortiz, and C. Mayorga Antolínez, "Curado natural y acelerado de una arcilla estabilizada con aceite sulfonado," Ing. y Desarro., no. 24, pp. 48-62, 2008.

[12] W. JvdM Steyn, "Applications of Nanotechnology in Road PavementEngineering," Nanotechnol. Civ. Infrastruct., pp. 49-83, 2011.

[13] Z. Ge and Z. Gao, "Applications of nanotechnology and nanomaterials in construction," First Inter. Confer. Construc. Dev. Ctries., pp. 235-240, 2008.

[14] J. M. Makar and J. J. Beaudoin, "Carbon nanotubes and their application in the construction industry," 1st Int. Symp. Nanotechnol. Constr., pp. 331-341, 2003.

[15] F. Jarrahzade and M. S. Bajestan, "Changing clay structure by nanotechnology due to soil," Int. Congr. Nanosci. Nanotechnol., pp. 1-2, 2010.

[16] S. S. Su and I. Chang, "Review of Production Routes of Nanomaterials," Commer. Nanotechnologies-A Case Study Approach, pp. 15-29, 2018.

[17] M. E. Abdullah et al., "A review on the exploration of nanomaterials application in pavement engineering," J. Teknol., vol. 73, no. 4, pp. 69-76, 2015.

[18] W. Steyn, "Research and application of nanotechnology in transportation," South. African Transp. Conf., no. July, pp. 345-353, 2008.

[19] S. Chandni Dipak and D. Srirama, "A review of stabilization of expansive soils by using nanomaterials," 50th INDIAN Geotech. Conf. 17th - 19th DECEMBER 2015, no. December, p. 8, 2015.

[20] W. Zhu, P. J. M. Bartos, and A. Porro, "Application of nanotechnology in construction Summary of a state-of-the-art report," Mater. Struct. Constr., vol. 37, no. 273, pp. 649-658, 2004.

[21] J. Koo, "An Overview of Nanoparticles," in Polymer Nanocomposites: Processing, Characterization and Applications, O. Manasreh, Ed. McGraw-Hill: New York, Chicago, San Francisco, Lisbon, London, Madrid, Mexico City, Milan, New Delhi, San Juan, Seoul, Singapore, Sydney, Toronto, 2006, pp. 9-49.

[22] D. A. Patel and C. B. Mishra, "Nano Material 
for Highway Infrastructure," Kalpa Publ. Civ. Eng., vol. 1, pp. 321-328, 2017.

[23] J. Larsen Basse and K. P. Chong, "Nanomaterials in construction and rehabilitation: Contributions and perspectives of the US National Science Foundation," NICOM 2 2nd Int. Symp. Nanotechnol. Constr., pp. 17-25, 2006.

[24] K. C. Onyelowe and F. O. Okafor, "Review of the synthesis of nano-sized ash from local waste for use as admixture or filler in engineering soil stabilization and concrete production," $J$. Environ. Nanotechnol., vol. 4, no. 4, pp. 23-27, 2015.

[25] T. W. Lambe and R. V. Whitman, Soil Mechanics. New York: John Wiley \& Sons, 1969.

[26] P. Luhana, J. Pitroda, and L. B. Zala, "Nanotechnology in Flexible Pavement," Int. J. Sci. Res., vol. 2, no. 1, pp. 10-12, 2013.

[27] L. J. Castillo, "State-of-the-art review of the applications of nanotechnology in pavement materials," Texas A\&M University-Kingsville, 2014.

[28] G. D. Lopez and M. S. Ambrosini, "Nanotechnology in Soil Stabilization :Economic Feasibility," in 13er Congreso Internacional en Ciencia y Tecnología de Metalurgia y Materiales 2013, 2016, no. August 2013, p. 8.

[29] W.P.Grogan andW.G. Johnson, "Stabilization of high plasticity clay and silty sand by inclusion of discrete fibrillated polypropylene fibers (fibergrids ${ }^{\circledR}$ ) for use in pavement subgrades," Washington, DC, 1994.

[30] A. S. Zaimoglu and T. Yetimoglu, "Strength Behavior of Fine Grained Soil Reinforced with Randomly Distributed Polypropylene Fibers,"
Geotech. Geol. Eng., vol. 30, no. 1, pp. 197-203, 2012.

[31] P. K. Pradhan, R. K. Kar, and A. Naik, "Effect of random inclusion of polypropylene fibers on strength characteristics of cohesive soil," Geotech. Geol. Eng., vol. 30, no. 1, pp. 15-25, 2012.

[32] W. R. Azzam, "Reduction of the ShrinkageSwelling Potential with Polymer Nanocomposite Stabilization," J. Appl. Polym. Sci., vol. 123, pp. 299-306, 2011.

[33] G. K. Athulya, S. Dutta, and J. N. Mandal, "Performance evaluation of stabilised soil-slag mixes as highway construction material," Int. J. Geotech. Eng., vol. 11, no. 1, pp. 51-61, 2017.

[34] S. Gelsefidi and S. Alireza, "Application of Nanomaterial to Stabilize a Weak Soil," Int. Conf. Case Hist. Geotech. Eng. - Seventh Int. Conf. Case Hist. Geotech. Eng. Apr, 2013.

[35] M. A. Pashabavandpouri and S. Jahangiri, "Effect of nano silica on swelling, compaction and strength properties of clayey soil stabilized with lime," J. Appl. Environ. Biol. Sci., vol. 5, pp. 538-548, 2015.

[36] F. Changizi and A. Haddad, "Strength properties of soft clay treated with mixture of nano-SiO2and recycled polyester fiber," J. Rock Mech. Geotech. Eng., vol. 7, no. 4, pp. 367-378, 2015 .

[37] Z. H. Majeed and M. R. Taha, "An Analysis on Geotechnical Properties of Soil with Different Nanomaterials An Analysis on Geotechnical Properties of Soil with Different Nanomaterials," no. December, pp. 92-104, 2016.

[38] J. L. Coo, Z. P. S. So, and C. W. W. Ng, "Effect of nanoparticles on the shrinkage properties of 
clay," Eng. Geol., vol. 213, pp. 84-88, 2016.

[39] M. R. Taha and O. M. E. Taha, "Influence of nano-material on the expansive and shrinkage soil behavior," J. Nanoparticle Res., vol. 14, no. 10, 2012.

[40] F. Changizi and A. Haddad, "Effect of nanocomposite on the strength parameters of soil," KSCE J. Civ. Eng., vol. 21, no. 3, pp. 676686, 2017.

[41] M. Zahedi, M. Sharifipour, F. Jahanbakhshi, and R. Bayat, "Nanoclay Performance on Resistance of Clay under Freezing Cycles," J. Appl. Sci. Environ. Manag., vol. 18, no. 3, pp. 427-434, 2014.

[42] N. Khalid and M. F. Arshad, "Influence of Nano-Soil Particles in Soft Soil Stabilization," Electron. J. Geotech. Eng., vol. 20, no. January 2015, pp. 731-738, 2015.

[43] A. A. Firoozi, M. R. Taha, and A. A. Firoozi, "Nanotechnology in Civil Engineering," Electron. J. Geotech. Eng., vol. 19, no. July 2016, p. 12, 2014.

[44] K. C. Onyelowe, "Nanosized palm bunch ash (NPBA) stabilisation of lateritic soil for construction purposes," Int. J. Geotech. Eng., no. October, pp. 1-9, 2017.

[45] P. P. Kulkarni and J. N. Mandal, "Performance assessment of stabilized soil with fly ash- nano material mixes," J. Geotech. Transp. Eng., vol. 3, no. 2, pp. 35-46, 2017.

[46] O. S. Aderinola and E. S. Nnochiri, "Stabilizing Lateritic Soil Using Terrasil Solution," Sel. Sci. Pap. - J. Civ. Eng., vol. 12, no. 1, pp. 19-28, 2017.

[47] O. O. . Ugwu, J. B. . Arop, C. U. . Nwoji, and N. N. . Osadebe, "Nanotechnology as a preventive engineering solution to highway infrastructure failures," J. Constr. Eng. Manag., vol. 139, no. 8, pp. 987-993, 2013.

[48] S. Roshni and S. P. Jeyapriya, "Experimental Study on the use of Nano Chemical and Cement in the modification of Subgrade," Int. J. Sci. Eng. Res., vol. 8, no. 3, pp. 1868-1872, 2017.

[49] M. Lotfalian, A. Parsakhoo, and A. Savadkoohi, "Improvement of forest road gravel surfacing quality by nano-polymer CBR PLUS," Croat. J. For. Eng., vol. 37, no. 2, pp. 345-352, 2016.

[50] S. E. Mousavi and A. Karamvand, "Assessment of strength development in stabilized soil with CBR PLUS and silica sand," J. Traffic Transp. Eng. (English Ed., vol. 4, no. 4, pp. 412-421, 2017.

[51] P. Govindasamy, M. R. Taha, J. M. A. Alsharef, and K. Ramalingam, "Influence of nanolime and curing period on unconfined compressive strength of soil," Appl. Environ. Soil Sci., vol. 2017, p. 9, 2017.

[52] Z. M. Huang, Y. Z. Zhang, M. Kotaki, and S. Ramakrishna, "A review on polymer nanofibers by electrospinning and their applications in nanocomposites," Compos. Sci. Technol., vol. 63, no. 15, pp. 2223-2253, 2003.

[53] M. Kurečič and M. Sfiligoj Smole, "Electrospinning: Nanofibre Production Method," Tekstilec, vol. 56, no. 1, pp. 4-12, 2013.

[54] M. Olvera Gracia, J. R. Aguilar Hernández, and T. Kryshtab, "Procesamiento de micro y nanofibras de polipirrol/óxido de polietileno/ nylon-6 por la técnica de electrohilado**Citación estilo Chicago Olvera-Gracia, Manuel, Jorge 
Ricardo Aguilar-Hernández, Tetyana Kryshtab. Procesamiento de micro y nanofibras de polipi," Ing. Investig. y Tecnol., vol. 14, no. 4, pp. 575581, 2013.

[55] J. Xue, J. Xie, W. Liu, and Y.Xia, "Electrospun Nanofibers: New Concepts, Materials, and Applications," Acc. Chem. Res., vol. 50, no. 8, pp. 1976-1987, 2017.

[56] J. B. Ramos, M. T. Rosas, F. Á. Belmontes, G. N. Velázquez, and F. R. De Valle, "Caracterización de nanofibras de carbón modificadas superficialmente con plasma de etileno," Prospectiva, vol. 9, no. 2, pp. 54-58, 2011.

[57] L. Ahmed Sbia, A. Peyvandi, P. Soroushian, J. Lu, and A. M. Balachandra, "Enhancement of Ultrahigh Performance Concrete Material Properties with Carbon Nanofiber," Adv. Civ. Eng., vol. 2014, 2014.

[58] A. Yazdanbakhsh, Z. Grasley, B. Tyson, and R. Abu Al-Rub, "Distribution of carbon nanofibers and nanotubes in cementitious composites," Transp. Res. Rec. J. Transp. Res. Board, vol. 2142, no. 2142, pp. 89-95, 2010.

[59] M. Jamal, A. Khattab, and H. R. Rizvi, "Characterization of carbon nano-fiber modified hot mix asphalt mixtures," Constr. Build. Mater., vol. 40, pp. 738-745, 2013.

[60] D. Cetin, T. Sengul, M. M. Khachan, S. K. Bhatia, and S. O. Owen, "Dewatering Performance of Fiber Reinforced Fly Ash Slurry," New Front. Geotech. Eng. GSP 243 (C) ASCE, pp. 98-107, 2014.

[61] C. Shin and G. G. Chase, "Nanofibers from recycle waste expanded polystyrene using natural solvent," Polym. Bull., vol. 55, no. 3, pp. 209-215, 2005.
[62] R. Johnson and K. Rangaswamy, "Improvement of soil properties as a road base material using nano chemical solution," 50th INDIAN Geotech. Conf. 17th-19th DECEMBER 2015, no. December, p. 10, 2015.

[63] S. M. Hejazi, M. Sheikhzadeh, S. M. Abtahi, and A. Zadhoush, "A simple review of soil reinforcement by using natural and synthetic fibers," Constr. Build. Mater., vol. 30, pp. 100116, 2012.

[64] Z. H. Majeed and M. R. Taha, "A Review of Stabilization of Soils by using Nanomaterials," Aust. J. Basic Appl. Sci., vol. 7, no. 2, pp. 576581, 2013.

[65] H. Jiang, Y. Cai, and J. Liu, "Engineering properties of soils reinforces by short discrete polypropylene fiber," J. Mater. Civ. Eng., vol. 22, no. 12, pp. 1315-1322, 2010.

[66] N. Phougat, "Stabilization of expansive soil," Int. J. Curr. Eng. Sci., vol. 6, no. 4, pp. 88-96, 2017.

[67] J. M. A. Alsharef, M. R. Taha, A. A. Firoozi, and P. Govindasamy, "Potential of using nanocarbons to stabilize weak soils," Appl. Environ. Soil Sci., vol. 2016, 2016.

[68] M. R. Taha, "Recent Developments in Nanomaterials for Geotechnical and Geoenvironmental Engineering Applications of Nanoparticles in Geotechnical and Geoenvironmental," MATEC Web Conf. 149, vol. 02004, pp. 4-8, 2018.

[69] M. R. Taha and J. M. A. Alsharef, "Use of nanocarbons to control swelling, shrinkage, and hydraulic conductivity of a residual soil," Proc. 2nd Symp. Coupled Phenom. Environ. Geotech., no. November, 2017. 
[70] J. M. A. Alsharef, M. R. Taha, and T. A. Khan, "Physical dispersion of nanocarbons in composites - A review," Technol. J., vol. 79, no. 5, pp. 69-81, 2017.

[71] J. M. A. Alsharef, M. R. Taha, R. A. AlMansob, and T. A. Khan, "Influence of carbon nanofibers on the shear strength and comparing cohesion of direct shear test and AFM," J. Nano Res., vol. 49, pp. 108-126, 2017. 